\title{
Facile Synthesis of Pyrazole- and Benzotriazole-Containing Selenoethers
}

\author{
Andrei S. Potapov, ${ }^{1,2}$ Nina P. Chernova, ${ }^{2}$ Vladimir D. Ogorodnikov, ${ }^{3}$ \\ Tatiana V. Petrenko, ${ }^{3}$ and Andrei I. Khlebnikov ${ }^{1,2}$ \\ ${ }^{1}$ Department of Biotechnology and Organic Chemistry, National Research Tomsk Polytechnic University, 30 Lenin Avenue, \\ Tomsk 634050, Russia \\ ${ }^{2}$ Department of Chemistry, Altai State Technical University, 46 Lenin Avenue, Barnaul 656038, Russia \\ ${ }^{3}$ Institute of Petroleum Chemistry, Siberian Branch of Russian Academy of Sciences, 3 Akademicheskii Avenue, \\ Tomsk 634055, Russia \\ Correspondence should be addressed to Andrei S. Potapov; asp99@yandex.ru
}

Received 8 September 2014; Accepted 4 November 2014; Published 20 November 2014

Academic Editor: Georgiy B. Shul'pin

Copyright ( $(2014$ Andrei S. Potapov et al. This is an open access article distributed under the Creative Commons Attribution License, which permits unrestricted use, distribution, and reproduction in any medium, provided the original work is properly cited.

Azole-containing selenoethers, 1,5-bis(3,5-dimethylpyrazol-1-yl)-3-selena pentane and 1,3-bis(1,2,3-benzotriazol-1-yl)-2-selena propane were prepared by the reaction of corresponding tosylate or chloride with sodium selenide generated in situ from elemental selenium and sodium formaldehydesulfoxylate (rongalite).

\section{Introduction}

Organoselenium compounds find applications due to their biological activity and useful synthetic properties (see $[1$, 2] and references cited therein). Selenoethers demonstrate potent ligating ability towards transition and main-group elements [3]. On the other hand, azole-containing thioethers are also known for their rich coordination chemistry [4]. Therefore, ligands carrying both azole- and selenoether moieties are especially interesting in view of their coordination chemistry. Nevertheless, only a few reports on compounds of this type have appeared in literature, demonstrating their use as building blocks for supramolecular architecture [5] and as ligands for catalysts [6-9]. Hodage et al. demonstrated potential glutathione peroxidase-like activity of some pyrazolecontaining selenoethers [10]. Recently, Pop et al. prepared a series of late transition metal complexes of pyrazole-derived selenoethers [11].

Dialkyl selenides (selenoethers) are usually prepared from alkyl halides and $\mathrm{Se}^{2-}$ species, generated from various selenium compounds. Since selenide ions are very unstable towards oxygen, they are generated in situ using different reducing agents. Selenium in combination with aqueous
$\mathrm{NaOH}$ [12], liquid ammonia and sodium [13], sodium in DMF [14], and sodium formaldehydesulfoxylate (rongalite) [15] were reported as sources of selenide ions. Other selenium compounds, such as selenium dioxide (reduced by trialkyl borohydrides) [16] or selenium tetrachloride [17], are less commonly used.

Herein we report improved methods for the preparation of pyrazole- and benzotriazole-containing selenoethers 1,5bis(3,5-dimethylpyrazol-1-yl)-3-selena pentane (2) and 1,3bis(1,2,3-benzotriazol-1-yl)-2-selena propane (4).

\section{Results and Discussion}

2.1. Synthesis of Selenoethers. In our preparation of azolecontaining selenoethers we used elemental selenium and sodium formaldehydesulfoxylate $\left(\mathrm{HOCH}_{2} \mathrm{SO}_{2} \mathrm{Na}\right.$, rongalite) in aqueous $\mathrm{NaOH}$ [18]. The generated in situ sodium selenide was introduced into the reaction with 1-(2-tosyloxy ethyl)3,5-dimethylpyrazole (1) or 1-chloromethyl benzotriazole (3) (Scheme 1). Due to low solubility of compound 3 in water acetonitrile was added to the reaction mixture in order to expedite the nucleophilic substitution. It should be noted that 

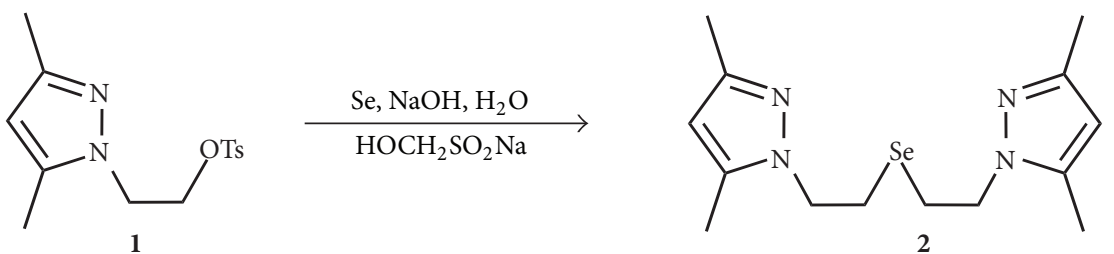<smiles>ClCn1nnc2ccccc21</smiles>
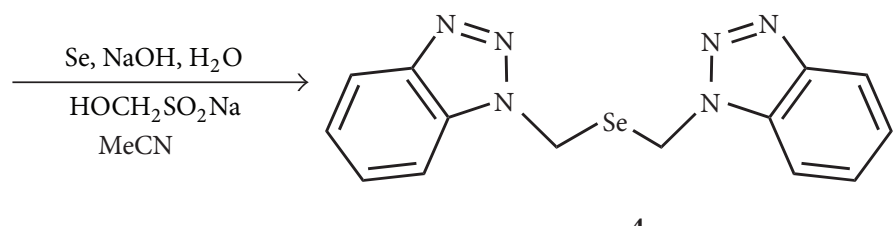

4

Scheme 1: Synthesis of azole-selenoethers.

we found it unnecessary to carry out the reactions under nitrogen atmosphere, which is probably due to reductive atmosphere created by $\mathrm{SO}_{2}$ evolution from the excess of rongalite. Pyrazole- and benzotriazole-containing selenoethers ( 2 and 4) were obtained in good yields (76 and 90\%) as offwhite air- and moisture-stable solids even in the absence of nitrogen atmosphere. It should be noted that in our synthetic procedure selenide ions were generated using inexpensive and stable rongalite in contrast to superhydride $\left(\mathrm{LiBEt}_{3} \mathrm{H}\right)$ or $\mathrm{NaBH}_{4}$ used in previously reported methods of preparation of selenoethers 2 [10] and 4 [19]. The structures of selenoethers were confirmed by IR and NMR spectroscopy and, in case of selenoether 2, electron-impact mass-spectrometry.

It is known [20] that upon reduction selenium can form diselenide ions $\mathrm{Se}_{2}{ }^{2-}$ in addition to selenides $\mathrm{Se}^{2-}$. Therefore, not only selenoethers, but also diselenides can form as a result of reactions in Scheme 1, and IR and NMR spectroscopy alone do not allow to unambiguously discern between them.

2.2. X-Ray Crystal Structure Determination. In order to establish the structures of compounds $\mathbf{2}$ and $\mathbf{4}$ we have carried out single crystal X-ray structure determinations. Single crystals of compound 4 were obtained by crystallization from acetonitrile. Compound $\mathbf{2}$ has a relatively low melting point and crystallized rapidly from various solvents, preventing the formation of single crystals. However, with copper(II) nitrate compound $\mathbf{2}$ readily gave well-formed crystals of complex suitable for X-ray structure determination. The complex $\left[\mathrm{Cu}(2)\left(\mathrm{NO}_{3}\right)_{2}\right]$ (5) was obtained in high yield $(84 \%)$; therefore selenoether $\mathbf{2}$ and not some other impurity acted as a ligand and the structure of the complex can be used for the elucidation of compound 2 structure.

Complex 5 crystallizes in a monoclinic crystal system; crystallographic parameters and details of the diffraction experiment are given in Table 1. Molecular structure of the complex is shown in Figure 1, and selected bond lengths and angles are listed in Table 2. From the structure of complex 5 it is evident that compound $\mathbf{2}$ is indeed a selenoether and not a diselenide. The lengths of $\mathrm{C}-\mathrm{C}$ and $\mathrm{C}-\mathrm{N}$ bonds in pyrazole rings are within the usual range [21]. The lengths of Se-C

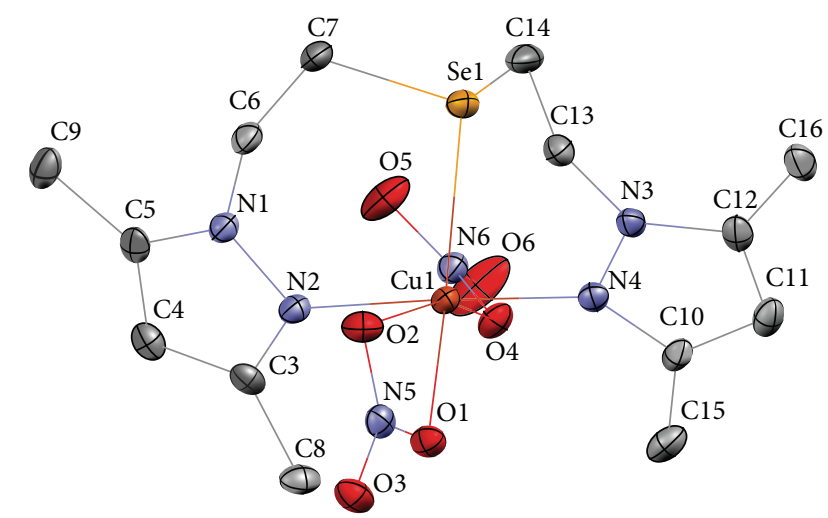

FIGURE 1: Molecular structure of compound 5. Thermal ellipsoids for nonhydrogen atoms are drawn at $50 \%$ probability level. Hydrogen atoms are omitted for clarity.

bonds (1.95-1.96 $\AA$ ) are also common for acyclic selenoethers [22].

Reports on the synthesis and crystal structure of benzotriazole-containing selenoether $\mathbf{4}$ have appeared in two recent papers. Lu et al. [23] used a nucleophilic substitution reaction of pure sodium selenide with chloro-derivative 2 to prepare the selenoether in 55\% yield. Das et al. [19] improved the yield up to $78 \%$ by generating $\mathrm{Na}_{2} \mathrm{Se}$ in situ from selenium and sodium borohydride. Both papers report crystal structures of prepared selenoethers, which they describe as pale-yellow crystals (m.p. $140^{\circ} \mathrm{C}$ [19]), readily soluble in common organic solvents. Both products appear to be the same monoselenide, and the slight differences in crystal structures are probably due to unlike packing fashion of formula units in elementary cells (monoclinic crystal system).

The crystallographic parameters, bond lengths, and angles for compound $\mathbf{4}$ are given in Tables 1 and 2 . The asymmetric unit of this compound is a monoselenide (Figure 2), and the elementary cell contains four such units. The molecular structure of selenoether $\mathbf{4}$ is very similar to those reported by Das et al. and Lu et al. [19, 23]. The lengths of Se-C bonds are slightly (by $0.01 \AA$ ) longer than in previously reported 
TABle 1: Crystallographic data, details of data collection, and structure refinement parameters for compounds $\mathbf{4}$ and $\mathbf{5}$.

\begin{tabular}{|c|c|c|}
\hline Example & 4 & 5 \\
\hline Chemical formula & $\mathrm{C}_{14} \mathrm{H}_{12} \mathrm{~N}_{6} \mathrm{Se}$ & $\mathrm{C}_{14} \mathrm{H}_{22} \mathrm{CuN}_{6} \mathrm{O}_{6} \mathrm{Se}$ \\
\hline $\mathrm{M}\left(\mathrm{g} \mathrm{mol}^{-1}\right)$ & 343.26 & 512.88 \\
\hline Temperature (K) & $100(2)$ & $100(2)$ \\
\hline Wavelength $(\AA)$ & 0.71073 & 0.71073 \\
\hline Crystal size (mm) & $0.14 \times 0.11 \times 0.11$ & $0.14 \times 0.11 \times 0.11$ \\
\hline Crystal system & Monoclinic & Monoclinic \\
\hline Space group & $\mathrm{P} 21 / \mathrm{c}$ & $\mathrm{P} 21 / \mathrm{c}$ \\
\hline$a(\AA)$ & $11.2605(8)$ & $16.8873(9)$ \\
\hline$b(\AA)$ & $9.1443(7)$ & $8.3578(5)$ \\
\hline$c(\AA)$ & $13.6312(10)$ & $13.9597(8)$ \\
\hline$\alpha\left(^{\circ}\right)$ & 90 & 90 \\
\hline$\beta\left(^{\circ}\right)$ & $102.2002(13)$ & $103.2610(10)$ \\
\hline$\gamma\left({ }^{\circ}\right)$ & 90 & 90 \\
\hline$V\left(\AA^{3}\right)$ & $1371.90(18)$ & 1917.74(19) \\
\hline$Z$ & 4 & 4 \\
\hline$D_{\text {calc }}\left(\mathrm{g} \mathrm{cm}^{-3}\right)$ & 1.662 & 1.776 \\
\hline$\mu\left(\mathrm{mm}^{-1}\right)$ & 2.740 & 3.082 \\
\hline$F\left(\begin{array}{lll}0 & 0 & 0\end{array}\right)$ & 688 & 1036 \\
\hline $\begin{array}{l}\theta \text { range for data } \\
\text { collection }\left({ }^{\circ}\right)\end{array}$ & 1.85 to 29.00 & 2.48 to 29.00 \\
\hline \multirow{3}{*}{ Index ranges } & $-15 \leq h \leq 15$ & $-23 \leq h \leq 23$ \\
\hline & $-12 \leq k \leq 12$ & $-11 \leq k \leq 11$ \\
\hline & $-18 \leq l \leq 18$ & $-19 \leq l \leq 19$ \\
\hline Reflections collected & 15771 & 22301 \\
\hline Independent reflections & $\begin{array}{c}3651 \\
{[R(\mathrm{int})=0.0446]}\end{array}$ & $\begin{array}{c}5086 \\
{[R(\text { int })=0.0661]}\end{array}$ \\
\hline Completeness to $2 \theta$ (\%) & 99.9 & 99.7 \\
\hline Absorption correction & $\begin{array}{l}\text { Semi-empirical } \\
\text { from equivalents }\end{array}$ & $\begin{array}{l}\text { Semi-empirical } \\
\text { from equivalents }\end{array}$ \\
\hline $\begin{array}{l}\text { Max. and min. } \\
\text { transmission }\end{array}$ & 0.753 and 0.700 & 0.913 and 0.694 \\
\hline Data/restraints/parameters & $3651 / 0 / 190$ & $5086 / 0 / 257$ \\
\hline Goodness-of-fit on $F^{2}$ & 1.002 & 1.018 \\
\hline Final $R_{1}, w R_{2}[I>2 \sigma(I)]$ & $\begin{array}{c}R_{1}=0.0276 \\
w R_{2}=0.0575\end{array}$ & $\begin{array}{c}R_{1}=0.0351 \\
w R_{2}=0.0677\end{array}$ \\
\hline$R_{1}, w R_{2}$ (all data) & $\begin{array}{c}R_{1}=0.0449 \\
w R_{2}=0.0643\end{array}$ & $\begin{array}{c}R_{1}=0.0572 \\
w R_{2}=0.0766\end{array}$ \\
\hline $\begin{array}{l}\text { Largest difference in peak } \\
\text { and hole }\left(\mathrm{e} \AA^{-3}\right)\end{array}$ & 0.434 and -0.433 & 0.590 and -0.604 \\
\hline
\end{tabular}

structures, while $\mathrm{C}-\mathrm{Se}-\mathrm{C}$ angle is slightly sharper. The major type of intermolecular interactions, that is, probably responsible for low solubility and high melting point of compound 4, is Se-Se contacts (3.7936(3) $\AA$, Figure 3), the length of which is in the range reported previously for selenoethers [24].

\section{Conclusion}

In summary, two selenoethers (pyrazole- and benzotriazolecontaining, 2 and 4) were prepared using elemental seleniumrongalite system for in situ selenide ion generation. The
TABLE 2: Selected bond distances $(\AA)$ and angles $\left(^{\circ}\right)$ for compounds 4 and 5.

\begin{tabular}{|c|c|c|c|}
\hline \multicolumn{4}{|c|}{ Compound 4} \\
\hline $\operatorname{Se}(1)-C(1 \mathrm{~A})$ & $1.960(2)$ & $\mathrm{N}(1 \mathrm{~A})-\mathrm{C}(1 \mathrm{~A})-\mathrm{Se}(1)$ & $112.83(14)$ \\
\hline $\operatorname{Se}(1)-C(1)$ & $1.962(2)$ & $\mathrm{C}(1 \mathrm{~A})-\mathrm{Se}(1)-\mathrm{C}(1)$ & $95.88(9)$ \\
\hline $\mathrm{N}(1)-\mathrm{C}(1)$ & $1.440(3)$ & $N(1)-C(1)-S e(1)$ & $111.81(13)$ \\
\hline $\mathrm{N}(1 \mathrm{~A})-\mathrm{C}(1 \mathrm{~A})$ & $1.441(3)$ & & \\
\hline \multicolumn{4}{|c|}{ Compound 5} \\
\hline $\operatorname{Se}(1)-C(7)$ & $1.955(3)$ & $\mathrm{C}(7)-\mathrm{Se}(1)-\mathrm{C}(14)$ & $99.87(12)$ \\
\hline $\operatorname{Se}(1)-C(14)$ & $1.965(3)$ & $\mathrm{C}(7)-\mathrm{Se}(1)-\mathrm{Cu}(1)$ & $101.55(8)$ \\
\hline $\mathrm{Se}(1)-\mathrm{Cu}(1)$ & $2.5110(4)$ & $\mathrm{C}(14)-\mathrm{Se}(1)-\mathrm{Cu}(1)$ & $100.47(8)$ \\
\hline $\mathrm{Cu}(1)-\mathrm{N}(4)$ & $1.965(2)$ & $\mathrm{N}(4)-\mathrm{Cu}(1)-\mathrm{N}(2)$ & $175.68(9)$ \\
\hline $\mathrm{Cu}(1)-\mathrm{N}(2)$ & $1.971(2)$ & $\mathrm{N}(4)-\mathrm{Cu}(1)-\mathrm{O}(1)$ & $88.00(8)$ \\
\hline $\mathrm{Cu}(1)-\mathrm{O}(1)$ & $2.0504(19)$ & $\mathrm{N}(4)-\mathrm{Cu}(1)-\mathrm{Se}(1)$ & $87.11(6)$ \\
\hline $\mathrm{Cu}(1)-\mathrm{O}(4)$ & $2.2700(19)$ & $\mathrm{N}(2)-\mathrm{Cu}(1)-\mathrm{Se}(1)$ & $95.72(6)$ \\
\hline
\end{tabular}

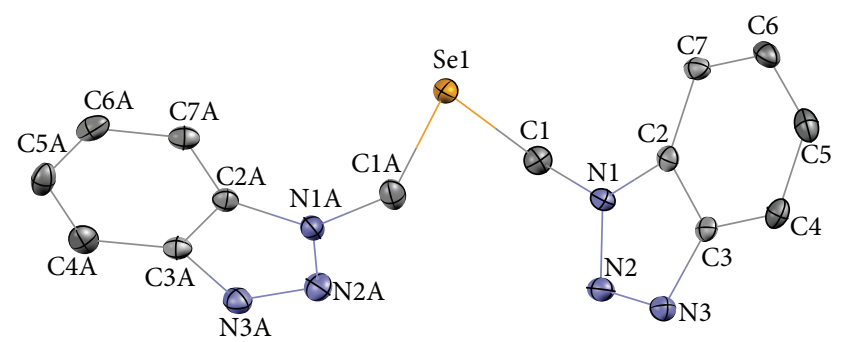

FIgUre 2: Molecular structure of selenoether 4. Thermal ellipsoids for nonhydrogen atoms are drawn at 50\% probability level. Hydrogen atoms are omitted for clarity.

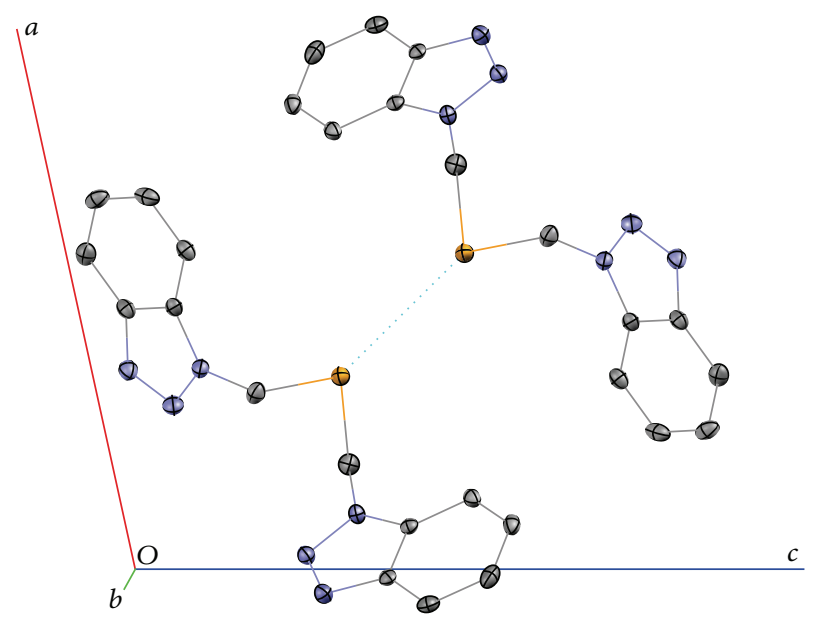

Figure 3: Se-Se intermolecular contacts in the structure of 4 . Some molecules in the unit cell are not shown for clarity.

proposed method uses inexpensive reagents, and provides higher yields compared to reported procedures.

\section{Experimental}

Elemental analyses were carried out on a Carlo Erba analyzer. Infrared (IR) spectra of solid samples as $\mathrm{KBr}$ pellets were 
recorded on a Nicolet $5700\left(4000-400 \mathrm{~cm}^{-1}\right)$ spectrophotometer. NMR spectra were recorded on Bruker AV300 instrument operating at $300 \mathrm{MHz}$ for ${ }^{1} \mathrm{H}$ and $75 \mathrm{MHz}$ for ${ }^{13} \mathrm{C}$. EI MS measurements were carried out using TRACE DSQ (Thermo Electron Corporation, USA) instrument.

Single crystals of compounds $\mathbf{4}$ and $\mathbf{5}$ for crystal structure determination were mounted in inert oil and transferred to the cold gas stream of the diffractometer. The structure was determined at $153 \mathrm{~K}$ by conventional single crystal $\mathrm{X}$ ray diffraction techniques using an automated four-circle Bruker-Nonius X8 Apex diffractometer equipped with a 2D CCD detector and graphite monochromated molybdenum source $(\lambda=0.71073 \AA)$. Intensity data were collected by $\varphi$ scanning of narrow frames $\left(0.5^{\circ}\right)$ to $2 \theta=54.96^{\circ}$. Absorption correction was applied empirically by the program SADABS [25]. The structure was solved by the direct method and refined using the full-matrix least-squares technique in the anisotropic approximation for nonhydrogen atoms with the program package SHELX-97 [26]. Hydrogen atoms were localized geometrically.

Tosylate 1 [27] and chloro-derivative 3 [28] were prepared according to known procedures; sodium formaldehydesulfoxylate dihydrate (rongalite) was purchased from Acros.

4.1. 1,5-Bis(3,5-dimethylpyrazol-1-yl)-3-selena Pentane (2). A suspension of selenium $(0.395 \mathrm{~g}, 5 \mathrm{mmol})$, sodium formaldehydesulfoxylate dihydrate $(3.08 \mathrm{~g}, 20 \mathrm{mmol})$, and $\mathrm{NaOH}$ $(1.10 \mathrm{~g}, 27.5 \mathrm{mmol})$ in water $(5 \mathrm{~mL})$ was stirred at room temperature, until the initially formed red solution turned colorless and white precipitate of $\mathrm{Na}_{2} \mathrm{Se}$ was formed (15$20 \mathrm{~min})$. Tosylate $\mathbf{1}(2.94 \mathrm{~g}, 10 \mathrm{mmol})$ was then added in one portion, the mixture was brought to reflux and stirring was continued for 3 hours (TLC control). After that water $(30 \mathrm{~mL})$ was added to the reaction mixture to dissolve the precipitated product and excess of rongalite. The solution obtained was extracted with chloroform $(5 \times 20 \mathrm{~mL})$; the extract was dried over anhydrous $\mathrm{Na}_{2} \mathrm{SO}_{4}$. After removal of solvent, slightly yellow oil was obtained, which crystallized on standing at room temperature. The product was recrystallized form hexane to give colorless crystals of selenoether 2 . Yield $1.24 \mathrm{~g}$ (76\%), mp 54-56 ${ }^{\circ} \mathrm{C}$ (hexane). IR $\left(\nu, \mathrm{cm}^{-1}\right) 1550,1460\left(\nu_{\mathrm{Pz}}\right)$, $1298\left(\delta_{\mathrm{C}-\mathrm{H}}, \mathrm{Pz}\right), 1026\left(\mathrm{Pz}\right.$ breating), $776\left(\nu_{\mathrm{C}-\mathrm{Se}}\right) .{ }^{1} \mathrm{H}$ NMR $\left(\mathrm{CDCl}_{3}\right): 2.16\left(\mathrm{~s}, 6 \mathrm{H}, 3-\mathrm{CH}_{3}-\mathrm{Pz}\right), 2.21$ (s, 6H, 5- $\left.\mathrm{CH}_{3}-\mathrm{Pz}\right), 2.81$ $\left(\mathrm{t}, 4 \mathrm{H}, J=7 \mathrm{~Hz}, \mathrm{PzCH}_{2} \mathrm{CH}_{2} \mathrm{Se}\right), 4.10(\mathrm{t}, 4 \mathrm{H}, J=7 \mathrm{~Hz}$, $\mathrm{PzCH}_{2} \mathrm{CH}_{2} \mathrm{Se}$ ), 5.73 (s, $\left.2 \mathrm{H}, 4-\mathrm{H}-\mathrm{Pz}\right) .{ }^{13} \mathrm{C} \mathrm{NMR}\left(\mathrm{CDCl}_{3}\right)$ : $11.0\left(5-\mathrm{CH}_{3}-\mathrm{Pz}\right), 13.3\left(3-\mathrm{CH}_{3}-\mathrm{Pz}\right), 23.3\left(\mathrm{PzCH}_{2} \mathrm{CH}_{2} \mathrm{Se}\right), 48.9$ $\left(\mathrm{PzCH}_{2} \mathrm{CH}_{2} \mathrm{Se}\right.$ ), 104.8 (4-C-Pz), 138.8 (5-C-Pz), 147.5 (3-C$\mathrm{Pz})$. EI-MS $(70 \mathrm{eV}): 326\left(\mathrm{M}^{+}\right), 230\left([\mathrm{M}-\mathrm{Pz}]^{+}\right), 203([\mathrm{M}-$ $\left.\left.\mathrm{PzCH}_{2} \mathrm{CH}_{2}\right]^{+}\right), 109\left(\left[\mathrm{PzCH}_{2}\right]^{+}\right)$. Anal. Calc'd for $\mathrm{C}_{14} \mathrm{H}_{22} \mathrm{~N}_{4} \mathrm{Se}$ (325.31): C, 51.59; H, 6.82; N, 17.22. Found: C, 51.97; H, 7.01; N, 17.70 .

4.2. 1,3-Bis(1,2,3-benzotriazol-1-yl)-2-selena Propane (4). Selenoether 4 was prepared similarly to compound $\mathbf{2}$ from $2.10 \mathrm{~g}$ (12.54 mmol) chloro-derivative $1,0.50 \mathrm{~g}(6.27 \mathrm{mmol})$ of selenium, $2.31 \mathrm{~g}(15.0 \mathrm{mmol})$ of sodium formaldehydesulfoxylate dihydrate, and $1.38 \mathrm{~g}(34.5 \mathrm{mmol})$ of $\mathrm{NaOH}$ in $6 \mathrm{~mL}$ of water and $15 \mathrm{~mL}$ of acetonitrile. Yield $1.94 \mathrm{~g}$ (90\%), colorless crystals, mp $182-183^{\circ} \mathrm{C}(\mathrm{DMF})$. IR $\left(\nu, \mathrm{cm}^{-1}\right) 1612,1496,1453$ $\left(\nu_{\mathrm{Bta}}\right), 754\left(\nu_{\mathrm{C}-\mathrm{Se}}\right) .{ }^{1} \mathrm{H}$ NMR (DMSO-d 6$): 6.19\left(\mathrm{~s}, 4 \mathrm{H}, \mathrm{CH}_{2}\right)$, $7.44(\mathrm{t}, 2 \mathrm{H}, 5-\mathrm{H}-\mathrm{Bta}, J=7.5 \mathrm{~Hz}), 7.58(\mathrm{t}, 2 \mathrm{H}, 6-\mathrm{H}-\mathrm{Bta}, J=$ $7.5 \mathrm{~Hz}$ ), 7.97 (d, 2H, 4-H-Bta, $J=8 \mathrm{~Hz}), 8.08$ (d, 2H, 7-H-Bta, $J=8 \mathrm{~Hz}) .{ }^{13} \mathrm{C}$ NMR $\left(\mathrm{DMSO}_{6}\right): 42.5\left(\mathrm{CH}_{2}\right), 111.1$ (7-C-Bta), 119.3 (4-C-Bta), 124.4 (5-C-Bta), 127.5 (6-C-Bta), 131.9 (8-CBta), 145.4 (9-C-Bta). Anal. Calc'd for $\mathrm{C}_{14} \mathrm{H}_{12} \mathrm{~N}_{6} \mathrm{Se}$ (343.25): C, 48.99; H, 3.52. Found: C, 49.30; H, 3.83.

4.3. 1,5-Bis(3,5-dimethylpyrazol-1-yl)-3-selena Pentane-Dinitrato Copper (5). To a solution of selenoether $2(0.065 \mathrm{~g}$, $0.2 \mathrm{mmol})$ in acetone $(0.2 \mathrm{~mL})$, solution of $\mathrm{Cu}\left(\mathrm{NO}_{3}\right)_{2} \cdot 3 \mathrm{H}_{2} \mathrm{O}$ $(0.048 \mathrm{~g}, 0.2 \mathrm{mmol})$ in acetone $(0.2 \mathrm{~mL})$ was added. After standing for 2 hours, deep-green crystals of the complex were formed, which were filtered, washed with acetone, and dried. The crystals were suitable for X-ray crystal structure determination. Yield $0.086 \mathrm{~g}(84 \%)$. IR $\left(\nu, \mathrm{cm}^{-1}\right)$ $1556\left(\nu_{\mathrm{Pz}}\right), 1026$ (Pz breating), $811\left(\nu_{\mathrm{C}-\mathrm{Se}}\right)$. Anal. Calc'd for $\mathrm{C}_{14} \mathrm{H}_{22} \mathrm{CuN}_{6} \mathrm{O}_{6} \mathrm{Se}$ (512.87): C, 32.79; H, 4.32; N, 16.39. Found: C, 33.04; H, 4.50; N, 15.96 .

\section{Conflict of Interests}

The authors declare that there is no conflict of interests regarding the publication of this paper.

\section{Acknowledgments}

The reported study was partially supported by RFBR, research Project no. 13-03-98033, and "Nauka" Project no. 4.774.2014/ K.

\section{References}

[1] A. J. Mukherjee, S. S. Zade, H. B. Singh, and R. B. Sunoj, "Organoselenium chemistry: role of intramolecular interactions," Chemical Reviews, vol. 110, no. 7, pp. 4357-4416, 2010.

[2] D. M. Freudendahl, S. A. Shahzad, and T. Wirth, "Recent advances in organoselenium chemistry," European Journal of Organic Chemistry, vol. 2009, no. 11, pp. 1649-1664, 2009.

[3] W. Levason, S. D. Orchard, and G. Reid, "Recent developments in the chemistry of selenoethers and telluroethers," Coordination Chemistry Reviews, vol. 225, no. 1-2, pp. 159-199, 2002.

[4] E. Bouwman, W. L. Driessen, and J. Reedijk, "Model systems for type I copper proteins: structures of copper coordination compounds with thioether and azole-containing ligands," Coordination Chemistry Reviews, vol. 104, no. 1, pp. 143-172, 1990.

[5] M. Seredyuk, M. Haukka, I. O. Fritsky et al., "Bis(3,5-dimethyl$1 H$-pyrazolyl)selenide-a new bidentate bent connector for preparation of $1 \mathrm{D}$ and 2D co-ordination polymers," Dalton Transactions, no. 29, pp. 3183-3194, 2007.

[6] D. Das, P. Singh, and A. K. Singh, "Palladium and half sandwich ruthenium(II) complexes of selenated and tellurated benzotriazoles: synthesis, structural aspects and catalytic applications," Journal of Organometallic Chemistry, vol. 695, no. 7, pp. 955$962,2010$.

[7] T. Chakraborty, K. Srivastava, H. B. Singh, and R. J. Butcher, "Selenoether ligand assisted Heck catalysis," Journal of Organometallic Chemistry, vol. 696, no. 13, pp. 2559-2564, 2011. 
[8] K. N. Sharma, H. Joshi, V. V. Singh, P. Singh, and A. K. Singh, "Palladium(ii) complexes of pyrazolated thio/selenoethers: syntheses, structures, single source precursors of Pd4Se and PdSe nano-particles and potential for catalyzing Suzuki-Miyaura coupling," Dalton Transactions, vol. 42, no. 11, pp. 3908-3918, 2013.

[9] A. Kumar, G. K. Rao, S. Kumar, and A. K. Singh, "Formation and role of palladium chalcogenide and other species in SuzukiMiyaura and heck $\mathrm{C}-\mathrm{C}$ coupling reactions catalyzed with palladium(II) complexes of organochalcogen ligands: realities and speculations," Organometallics, vol. 33, no. 12, pp. 29212943, 2014.

[10] A. S. Hodage, P. P. Phadnis, A. Wadawale, K. I. Priyadarsini, and V. K. Jain, "Synthesis, characterization and structures of 2-(3,5-dimethylpyrazol-1-yl) ethylseleno derivatives and their probable glutathione peroxidase (GPx) like activity," Organic and Biomolecular Chemistry, vol. 9, no. 8, pp. 2992-2998, 2011.

[11] A. Pop, D. Rosca, R. Mitea, and A. Silvestru, "New diorganoselenium(II) compounds and their behavior toward late transition metals," Inorganica Chimica Acta, vol. 405, pp. 235-242, 2013.

[12] W. R. McWhinnie, "Organoselenium and organotellurium analogues of ethers and peroxides," in The Chemistry of Organic Selenium and Tellurium Compounds, S. Patai and Z. Rappoport, Eds., vol. 2, pp. 495-539, John Wiley \& Sons, Chichester, UK, 1987.

[13] R. Paetzold, U. Lindner, G. Bochmann, and P. Z. Reich, "Untersuchungen an Selen-Sauerstoff-Verbindungen. XLII. Dimethylund Diäthylselenoxid sowie ihre Oxoniumsalze Darstellung, Eigenschaften und Schwingungsspektren," Zeitschrift für Anorganische und Allgemeine Chemie, vol. 352, pp. 295-308, 1967.

[14] D. J. Sandman, J. C. Stark, L. A. Acampora, and P. Gagne, "A direct broadly applicable approach to the synthesis of aromatic molecular and supramolecular selenium and tellurium compounds," Organometallics, vol. 2, no. 4, pp. 549-551, 1983.

[15] M. L. Bird and F. Challenger, "113. Potassium alkaneselenonates and other alkyl derivatives of selenium," Journal of the Chemical Society (Resumed), pp. 570-574, 1942.

[16] E. Tsuchida and K. Honda, "Polarographic studies on redox reactivity of polymer-hemin complex in a hydrophobic microenvironment," Chemistry Letters, vol. 4, no. 2, pp. 119-122, 1975.

[17] H. M. Leicester, "The reactions between mercury diaryls and selenium tetrabromide," Journal of the American Chemical Society, vol. 60, no. 3, pp. 619-620, 1938.

[18] G. Sommen, A. Comel, and G. Kirsch, "Substituted selenophenes starting from ketene dithioacetals and sodium selenide," Synlett, no. 6, pp. 855-857, 2003.

[19] D. Das, M. Singh, and A. K. Singh, "Reactions of $\mu$-dichlo$\operatorname{robis}\left(\eta^{3}\right.$-allyl)palladium(II) with bis(1- $H$-benzo-triazolylmethyl) selenide: Formation of unexpected polymeric structure with dormant Se donor site. Applications of the polymeric Pdcomplexes in Heck coupling," Inorganic Chemistry Communications, vol. 12, pp. 1120-1123, 2009.

[20] W. Levason and G. Reid, "Recent developments in the chemistry of thio-, seleno- and telluro-ethers," in Handbook of Chalcogen Chemistry: New Perspectives in Sulfur, Selenium and Tellurium, F. A. Devillanova, Ed., pp. 81-106, The Royal Society of Chemistry, Cambridge, UK, 2007.

[21] A. R. Katritzky, C. A. Ramsden, J. A. Joule, and V. V. Zhdankin, Handbook of Heterocyclic Chemistry, Elsevier, Amsterdam, The Netherlands, 2010.
[22] I. Hargittai and B. Rozsondai, "Structural chemistry of organic compounds containing selenium or tellurium," in The Chemistry of Organic Selenium and Tellurium Compounds, S. Patai and Z. Rappoport, Eds., vol. 1, pp. 63-155, John Wiley \& Sons, Chichester, UK, 1986.

[23] Y. Lu, Y. Tang, H. Gao, Z. Zhang, and H. Wang, "The synthesis, crystal structures and SOD activities of a new ligand $\left(\mathrm{L}^{\text {se }}\right)$ and $\mathrm{Co}\left(\mathrm{L}^{\text {se }}\right)_{2}(\mathrm{SCN})_{2}$ complex $\left[\mathrm{L}^{\text {se }}=\right.$ selenium ether bis- $(N-$ 1-methyl- benzotriazole)]," Applied Organometallic Chemistry, vol. 21, no. 4, pp. 211-217, 2007.

[24] M. A. Petrukhina, C. Henck, B. Li et al., "Spirocyclic sulfur and selenium ligands as molecular rigid rods in coordination of transition metal centers," Inorganic Chemistry, vol. 44, no. 1, pp. 77-84, 2005.

[25] G. M. Sheldrick, SADABS Program for Empirical X-Ray Absorption Correction, Bruker-Nonius, 1990-2004.

[26] G. M. Sheldrick, "Foundations of crystallography," Acta Crystallographica A, vol. 64, pp. 112-122, 2008.

[27] W. G. Haanstra, W. L. Driessen, J. Reedijk, U. Turpeinen, and R. Hamalainen, "Unusual chelating properties of the ligand 1,8-bis(3,5-dimethyl-1-pyrazolyl)-3,6-dithiaoctane (bddo). Crystal structures of $\mathrm{Ni}($ bddo $)(\mathrm{NCS})_{2}, \mathrm{Zn}$ (bddo)(NCS $)_{2}$ and $\mathrm{Cd}_{2}$ (bddo)(NCS) $)_{4}$, Journal of the Chemical Society, Dalton Transactions, no. 11, pp. 2309-2314, 1989.

[28] J. H. Burckhalter, V. C. Stephens, and L. A. R. Hall, "Proof of structures derived from the hydroxy- and amino-methylation of benzotriazole," Journal of the American Chemical Society, vol. 74, no. 15, pp. 3868-3870, 1952. 

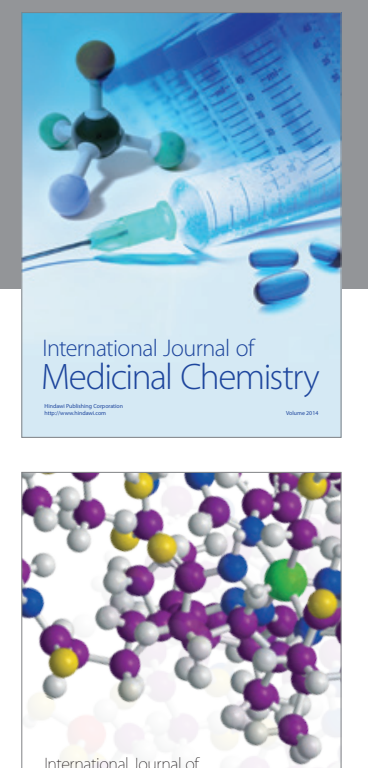

\section{Carbohydrate} Chemistry

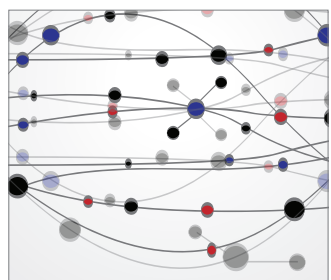

The Scientific World Journal
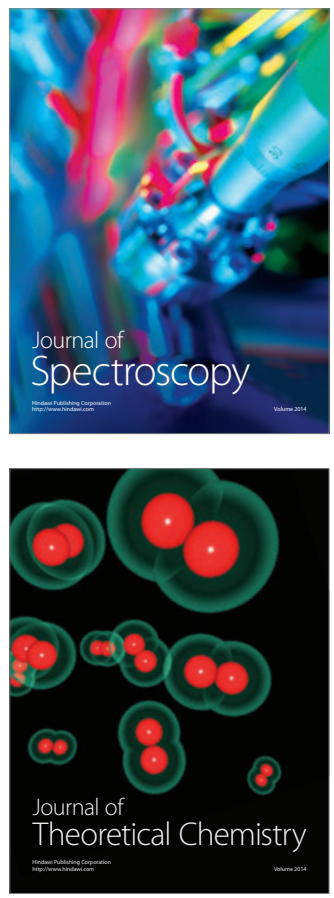
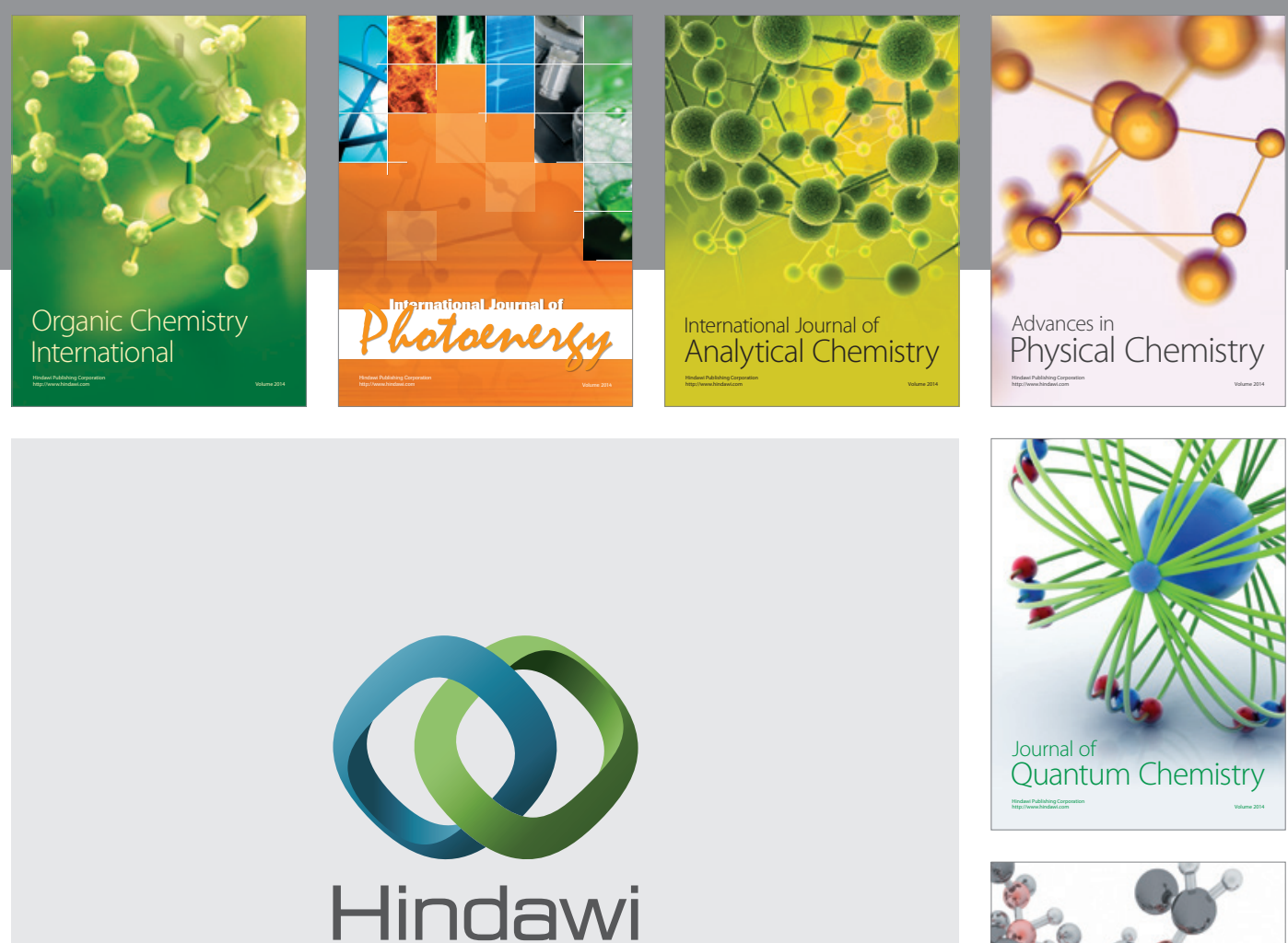

Submit your manuscripts at

http://www.hindawi.com

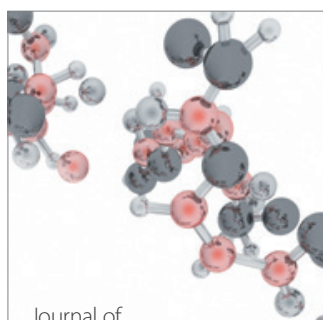

Analytical Methods

in Chemistry

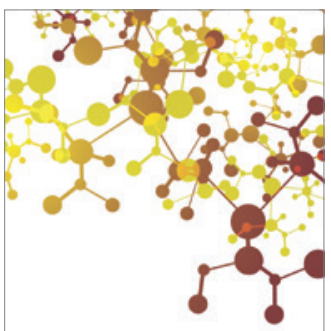

Journal of

Applied Chemistry

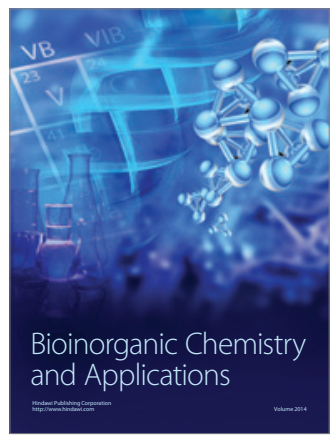

Inorganic Chemistry
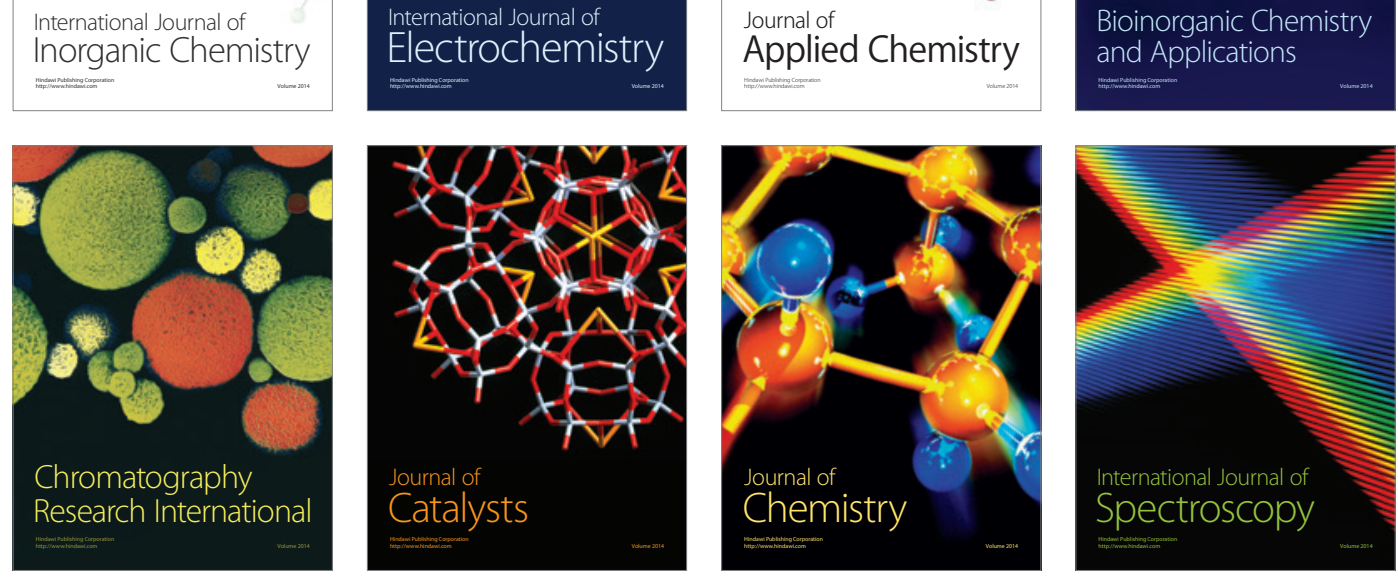